\title{
ALLELOPATHIC POTENTIAL OF RED SPRANGLETOP (Leptochloa chinensis L.) AGAINST GERMINATION AND SEEDLING GROWTH OF RICE (Oryza sativa L.)
}

\author{
Muhammad Sikander Hayyat ${ }^{1 *}$, Muhammad Ehsan Safdar ${ }^{1}$, Muhammad Mansoor \\ Javaid $^{1}$
}

DOI: https://doi.org/10.28941/pjwsr.v27i2.922

\begin{abstract}
Red sprangletop (Leptochloa chinensis L.) is a problematic weed of aerobic rice (Oryza sativa L.) that greatly reduces in yield. The laboratory studies were undertaken to confirm allelopathic potential of its plant leachates and soil-decomposition plant residues towards emergence and seedling growth of rice. In first experiment, aqueous extracts from various plant parts of red sprangletop (stem, root, leaves, flower and entire plant) at their $5 \%(w / v)$ concentration were applied to germinating rice seeds. In second experiment, soildecomposed red sprangletop plant residues of variable concentrations (2, 4 and $6 \% \mathrm{w} / \mathrm{w}$ ) were used as germination media for rice. Among plant parts, red sprangletop leaves showed maximum allelopathic effect by fully inhibiting the germination of rice while its stem could be positioned at second situation as it caused 60,73, 84, 13 and $86 \%$ reductions in germination percentage, germination index, seedling length and seedling dry biomass of rice as compared with control, respectively. This treatment also resulted in maximum delays in mean germination time (up to 4.80 days with $S E=0.408$ ) and days taken to $50 \%$ germination (up to 4.40 days with $S E=0.431$ ) of rice. The highest concentrated $(6 \%)$ soildecomposed plant residue of red sprangletop significantly reduced the germination percentage, germination index, seedling length and seedling vigor index by 35.13, 23.26 and $41.61 \%$ compared to control. It very well may be presumed that liquid concentrates of leave and stem soil-decomposed plant residues of $6 \%$ concentration had different kind of allelochemicals that inhibited the germination, seedling growth and development of rice.
\end{abstract}

Key words: Leptochloa chinensis, allelopathy, germination, growth, decomposition.

Citation: Muhammad, S.H., M.E. Safdar, M.M. Javaid. 2021. Allelopathic potential of red sprangletop (Leptochloa chinensis L.) Against germination and seedling growth of rice (Oryza sativa L.). Pak. J. Weed Sci. Res., 27 (2):139-152.

\footnotetext{
${ }^{1}$ Department of Agronomy, College of Agriculture, University of Sargodha, Sargodha, PK40100 Punjab, Pakistan.

*Corresponding Author: agrarianhayyat@yahoo.com

ORCID of corresponding author: 0000-0003-0148-1515
} 


\section{INTRODUCTION}

Numbers of undesirable plant species has ability to produce different chemicals known as allelochemicals. Allelopathy refers to direct or oblique, harmful or advantageous effect of one plant to another plant by the release various substances into the soil environment (Molisch, 1937; Rice, 1984). These allelochemicals are discharged from various plants that may influence the germination and development of other plant species (Einhelling, 1987). These chemicals might be eroded directly from the deposits, or may result from microbial action during putrefaction (Kumar et al., 2006). Allelopathy is the secondary metabolisms that are released under favorable condition into the soil environment by different mechanisms that include residues decomposition, root exudation and volatilization (Weston, 2005). Phytotoxic influence of weeds fluctuates from species to species (Hamayun et al., 2005). Different reports have been documented that allelopathicity of decomposed plant material on the growth and yield of subsequent crop (Shaukat et al., 2003; Burhan , Shaukat, 1999), similarly phytotoxic effect of different plant part of various weeds also showed significantly effect on performance of different plant species (Aziz et al., 2008; Economou et al., 2002). Khan et al. (2004) stated that due to weeds, agricultural crops and forest yield reduced due to competition.

Number of weeds has been reported that chemicals released from different plant parts influenced the emergence and growth of various crops due toxicity (Fischer and Quijano, 1985). Allelopathic influence of weeds as well as its competition for basic requirement of plant decreases the germination and yield of crops (Florkowski, Landry, 2002). Annual rice yield was reduced about 15$20 \%$ due to weed infestation (Karim et al., 2004). according to (Sawatdikarn, 2009) crude extract at $75 \mathrm{mg} / \mathrm{ml}$ inhibit the germination of watermelon, pumpkin and cucumber with $32.83,76.43$ and $71.61 \%$ and pigweed, alyceclover and wild spider with 85.69, 42.85 and $70.12 \%$ respectively also shy the seedling length and seedling dry biomass of target species. Phytotoxicity of watery concentrate of $T$. portulacastrum were significantly reduced the germination and seedling development of rice (Mubeen et al., 2011).

According to (Katoch et al., 2012) decomposed plant materials significantly hampered the emergence and growth performance of emerged seedling of target crops. Remains of sphagneticola trilobata inhibited the emergence of weeds up to 31.6 to $72 \%$ progressively with pragmatic dose. Entirely residues inhibit the dicotyledonous germination (Hernandez-Aro et al,. 2016). Leptochloa chinensis $\mathrm{L}$. is an emerging annual weed in direct seeded as well as puddled rice in Pakistan. It is originated in tropical region of Asia and then distributed in South East Asia. The genus leptochloa belongs to family poaceae having 45 species spreading tropical and sub- tropical areas (Macfarlane, 1987). It is used as fodder crop, normally known as serious weed in paddy fields. Because of abundant seed produces, various part of East Africa its grains in used as famine food. Its seedling developed quickly and they can keep pace with the raising level of flood water and thus survive.

Keeping in assessment the phytotoxic effect of different weeds on diverse crops, a comprehensive study was conducted to evaluate the allelopathy and soil decomposed residues of $L$. chinensis on germination and growth of fine grain rice.

\section{MATERIAL AND METHODS}

The experiment was performed in laboratory of Agronomy, College of Agriculture, University of Sargodha, in the year 2019, to estimate the phytotoxic potential of aqueous extract and soil decomposed plants of $L$. chinensis on germination and growth of fine grain rice (Oryza sativa L). In first trial aqueous extract $5 \%(\mathrm{w} / \mathrm{v})$ of various plant parts root, leaves, stem, inflorescence and 
entire plant were applied to seed of rice and distilled water were pragmatic as control treatment for comparison. In second experiment soil decomposed plant materials of $L$. chinensis having various concentrations (2, 4 and $6 \%$ ) used as germination media for rice. In both of the experiment "Super basmati" rice was used. The trials were spread out as completely randomized design having four replications. Both of examinations were rehashed and the consequences of second were considered and represent.

\section{Collection of experimental materials}

Fully vegetative plants of $L$. chinensis were uprooted from the rice field, research area department of Agronomy, College of Agriculture, University of Sargodha during the year 2019. Soil were collected from area without any vegetation, put into plastic bag and kept in laboratory.

\section{Preparation of aqueous extract}

Aqueous extract of $L$. chinensis was prepared by collecting the actively growing plants of $L$. chinensis from research area and the root, stem, leaves and flowers were separated then drying at room temperature. Afterward, samples were kept into oven at $70^{\circ} \mathrm{C}$ for the period of 48 hours. After drying separated part were grinded by using electric grinder. The powdered material was saturated in distilled water with 1:20 plant: distilled water $(\mathrm{w} / \mathrm{v})$ ratio and put into shaker (ISRDV1) for the period of 24 hours. Firstly the mixture were sieved with muslin cloth and then collecting extract sieved by using extraction assembly (AS20). The extracts of various plant parts were preserved in separate plastic bottle.

For the decomposition process, whole dry plant was grinded by using electrical grinder and the powdered material with different concentrations were mixed in $200 \mathrm{~g}$ of soil. The plant material and soil mixture will be kept for 60 days at room temperature for decomposition processes. Those soils were used as germination media for rice. Electrical conductivity (JANWAY-4510) and $\mathrm{pH}$ (JANWAY-3510) of aqueous extract and physiochemical analysis of soil before mixing of plant material were shown in Table-1.

Table-1: Electrical conductivity (EC) and $\mathrm{pH}$ of various plant parts of aqueous extracts and physiochemical analysis of soil.

\begin{tabular}{|l|c|c|c|c|c|}
\hline \multirow{2}{*}{ Extracts } & \multicolumn{2}{|c|}{ Aqueous extracts } & \multicolumn{2}{c|}{ Physiochemical analysis of soil } \\
\cline { 2 - 6 } & EC $\boldsymbol{\mu s}$ & $\mathbf{p H}$ & Soil pH & - & 7.6 \\
\cline { 2 - 6 } & 3.91 & 7.61 & EC & $\mathrm{dS} \mathrm{cm}^{-1}$ & 0.81 \\
\hline Distill water & 27.0 & 6.8 & $\begin{array}{c}\text { Organic } \\
\text { matter }\end{array}$ & $\%$ & 0.77 \\
\hline Root extract & 35.0 & 3.6 & Nitrogen N & $\%$ & 0.061 \\
\hline Stem extract & 174.5 & 1.9 & Available P & $\mathrm{mg} \mathrm{kg}^{-1}$ & 7.39 \\
\hline $\begin{array}{l}\text { Leaves } \\
\text { extract }\end{array}$ & 36.7 & 6.4 & Available K & $\mathrm{mg} \mathrm{kg}^{-1}$ & 154.4 \\
\hline $\begin{array}{l}\text { Flower } \\
\text { extract }\end{array}$ & 27.0 & 6.8 & Texture & - & Loam \\
\hline $\begin{array}{l}\text { Whole plant } \\
\text { extract }\end{array}$ & & & &
\end{tabular}

\section{Germination and growth condition}

In first experiment, ten seeds of "super basmati" rice were scattered in 9 $\mathrm{cm}$ diameter of petri plates having dual stratum of filter paper and $4 \mathrm{ml}$ of aqueous extracts of various plant part 
were applied then raped by Para film to avoid evaporation. A control treatment was added for comparison that was received distilled water. In second experiment, after 60 days of decomposition process ten seeds of rice were sown in pot having various concentrations $(2,4$ and $6 \%)$ of $L$. chinensis plant soil mixture after sowing $10 \mathrm{ml}$ of distilled water was applied and further irrigation were applied as per requirement. Together petri plates and pots were preserved in germinator at $35^{\circ} \mathrm{C}$ for the periods of 15 days. The data was recorded on regular basis.

\section{Data recording and calculations}

After the completion of germination

in both experiments, germination percentage, germination index, mean germination time and time taken to $50 \%$ were calculated by using following formulas.

\section{Germination/emergence percentage} was deliberate by subsequent formula:

$$
G P / E P=\frac{\text { Germinated } / \text { emerged seeds }}{\text { Total seeds }} \times 100
$$

\section{Germination index was calculated by} following formula:

$$
\begin{aligned}
& \text { GI/EI } \\
& =\frac{\text { No. of germinated/emerged seeds }}{\text { Days of first count }} \\
& +\frac{\text { No. of germinated/emerged seeds }}{\text { Days of final count }} \\
& \text { Mean germination time } \\
& \text { calculated by following formula: }
\end{aligned}
$$

$M G T / M E T=\frac{\Sigma \mathrm{Dn}}{\Sigma \mathrm{Dn}} \quad$ (Ellis and Roberts, 1981)

Anywhere $\mathrm{n}$ is the quantity of seeds that had germinated/emerged on day " $D$ " and $D$ is the quantity of days tallied from the earliest starting point of germination/emergence.

Time taken to $50 \%$ germination was calculated by following formula:

$$
T 50=\mathrm{ti}+\frac{(\mathrm{N} / 2-\mathrm{ni})(\mathrm{tj}-\mathrm{ti})}{(\mathrm{nj}-\mathrm{ni})}
$$

(Coolbear et al., 1984; Farooq et al., 2005)
Where $\mathrm{N}$ is the last count of sprouted/developed seeds and $\mathrm{ni}$ and $\mathrm{nj}$ are the total count of seeds sprouted/rose by nearby tallies at time ti and $\mathrm{tj}$, separately, where ni $<\mathrm{N} / 2<\mathrm{nj}$.

Seedling vigor index (SVI): (Orchard, 1977)

$$
\begin{gathered}
\text { SVI }= \\
{[\text { seedling length }(\mathrm{cm}) \times} \\
\text { Germination/emergence percentage] } \times 100
\end{gathered}
$$

The data regarding root-shoot length, root-shoot fresh and dry biomass, seedling length and seedling biomass were calculated by using standard method.

\section{Statistical analysis}

The composed data were collected to analyze statistically by using Fisher's analysis of variance technique by using Statistix 8.1 computer software. The highest significant difference (HSD) test was used for mean comparison at 0.05 (5\%) probability levels.

\section{RESULTS AND DISCUSSIONS}

\section{Germination parameters}

Weeds create hindrance against the germination of crop planta and also reduced the growth of plant due to its phytotoxic action, ultimately reduce per hectare yield of different crops. A study was conducted to evaluate the performance of rice as inclined by the watery extract of different plant parts of Leptochloa chinensis. Germination\% of rice was significantly reduced by the influenced of aqueous extract of various plant parts of $L$. chinensis. Results from the fig-1 ( $A, C, E$ ) and fig-2 (A) shows that aqueous extract of leaves fully inhibit the germination percentage (GP), germination index (GI), mean germination time (MGT) and time taken to $50 \%$ germination of rice seeds. This might be due to allelochemicals that were present in leaves of $L$. chinensis whereas stem and flower extract show 40 and $60 \%$ germination but statistically at par. Maximum (100\%) germination was observed when distilled water was applied (control treatment) which was statistically 
at par with root and whole plant extract $(92.50 \%)$. Our consequences are comparable with the observation of (Tanveer et al., 2008) who authenticated that leaves concentrates of Xanthium strumarium inhibit the GP and GI of rice seed, similarly (Sawatdikarn, 2009) documented that crude extract of red sprangletop highly suppress the germination of watermelon, pumpkin and cucumber with $32.83,76.43$ and $71.61 \%$ respectively.

In case of soil decomposed plant material (fig-1-B, D and F) and fig-2 (B) minimum GP (60\%), GI (7.65), MGT (4.79 days) and $\mathrm{T}_{50}$ (4.28 days) were recorded from pots having $6 \%$ decomposed plant material which was statistically at par with 2 and $4 \%$ soil decomposed plants of $L$. chinensis. At high concentration of decomposed material of $L$. chinensis, reduced germination percentage of rice. Our results are according with the findings of (Hernandez-Aro, 2016) who stated that residues of Sphagneticola trilobata significantly inhibited the germination of weeds, allelopathic potential increase with the increase in residues percentage/concentration. Various phytotoxic substances that released from the decomposed plant litter inhibit the biochemical and physiological process of seed germination (Weir et al., 2004) or may inhibit absorption of water (Turk, Tawaha, 2003).

\section{Growth parameters}

Data regarding Root and shoot length of rice plants influenced by aqueous extract and soil decomposed plant materials of $L$. chinensis is presented in Figures 2(C \& E). Data indicated that aqueous extract of leaf expressively inhibited the shoot and root length while highest values (2.13 and $3.04 \mathrm{~cm}$ ) accordingly were recorded when distilled water was applied. Root extract of $L$. chinensis reduced the germination of rice seeds but little bit enhanced the shoot growth as compared to other aqueous extract of $L$. chinensis plant parts (Figure 1). Similar results were documented by (Hayyat et al., 2020) who stated that shoot and root growth of crops significantly reduced by the application of weed aqueous extract.

In $6 \%$ soil decomposed plant material root and shoot length (4.27 and $11.52 \mathrm{~cm}$ ) was significantly reduced owing to direct interaction with allelochemicals that are contemporary in decomposed soil material while the maximum were observed in soil without any decomposed material (Control). The Figure 3 (A \& B) showed that leaf 
144 Muhammad Sikandar Hayat, Muhammad Ihsan Safdar et. al. Allelopathic potential of ...

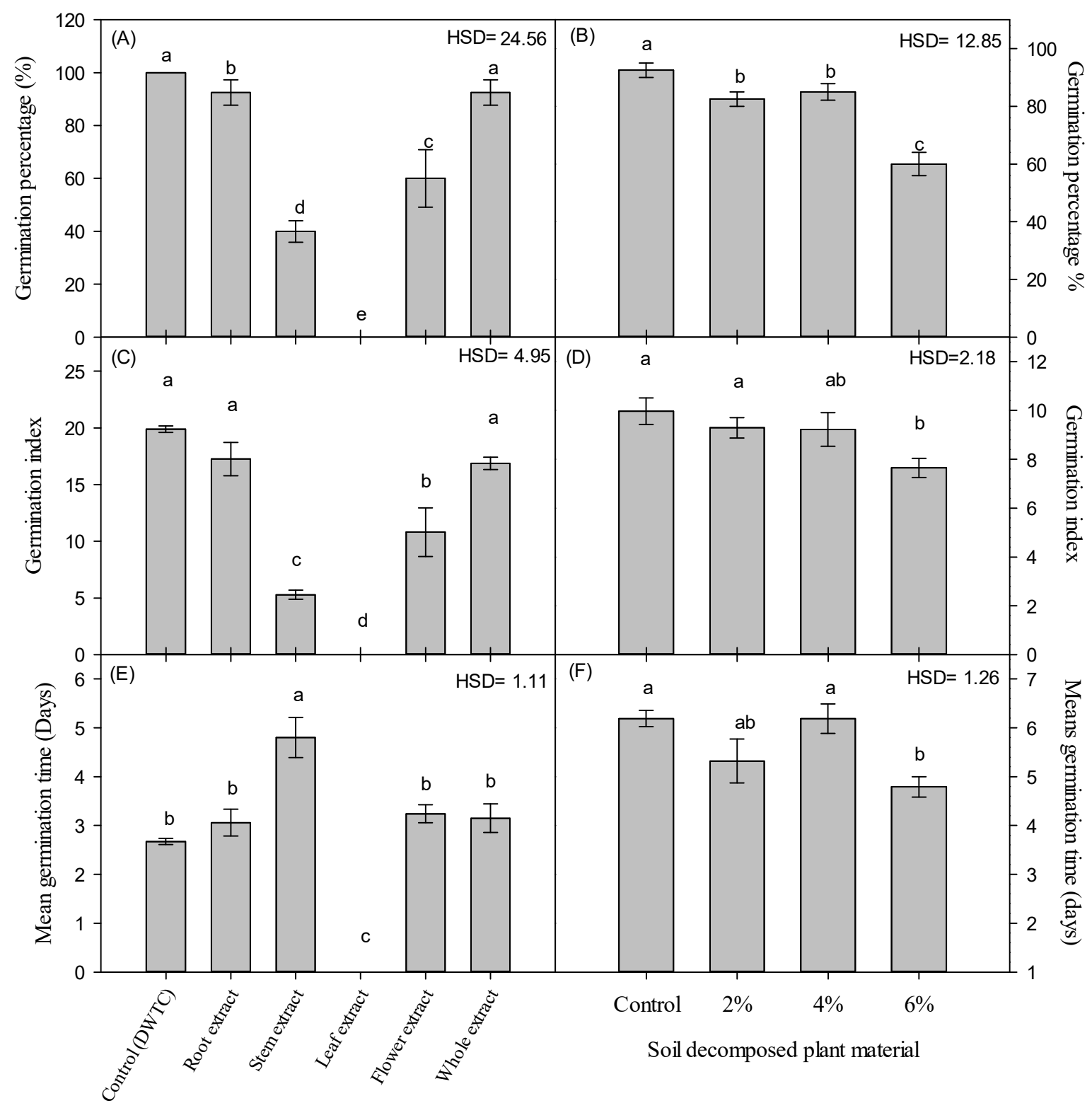

Figure-1: phytotoxic effect of various plant parts and soil decomposed plant material of $L$. chinensis on germination of rice. 


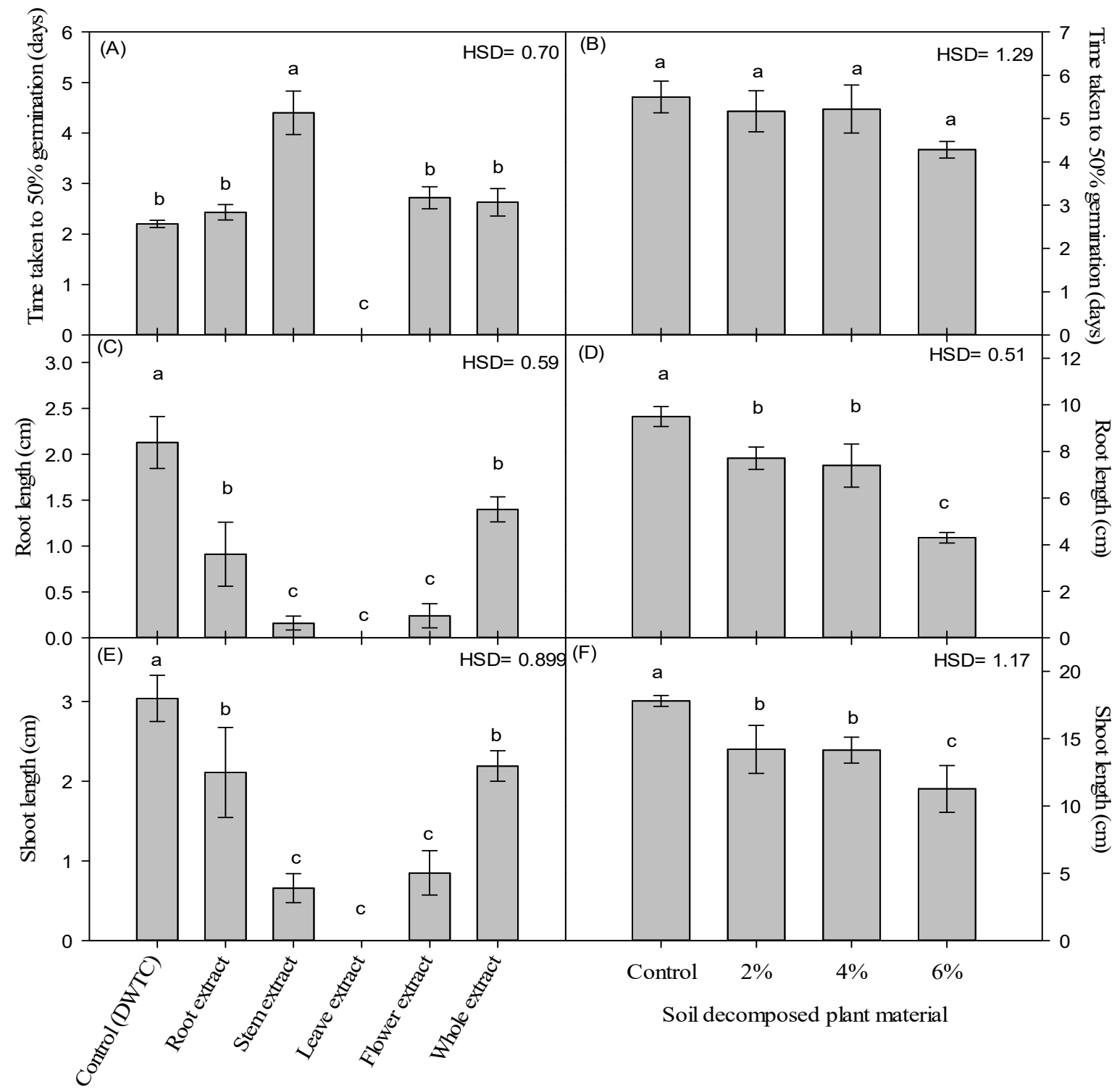

Figure-2: phytotoxic effect of various plant parts and soil decomposed plant material of $L$. chinensis on germination and seedling growth of rice.

extract and $6 \%$ plant decomposed material inhibit the seedling length of rice plant, highest seedling length were recorded in controlled condition. Shoot and root fresh weights of plant were important indicator of plant growth vigor data were presented in Figure 3.

Among aqueous extract of $L$. chinensis plant parts, maximum shoot and root fresh weights were chronicled in control condition (137 and $64 \mathrm{mg}$ ) but statistically similar with root and whole plant extract Figures 3 ( $C$ \& E). Leaf extract of $L$. chinensis fully inhibited both germination and growth of rice seed. From Figures 2 $(D, F)$, it is obvious that among 


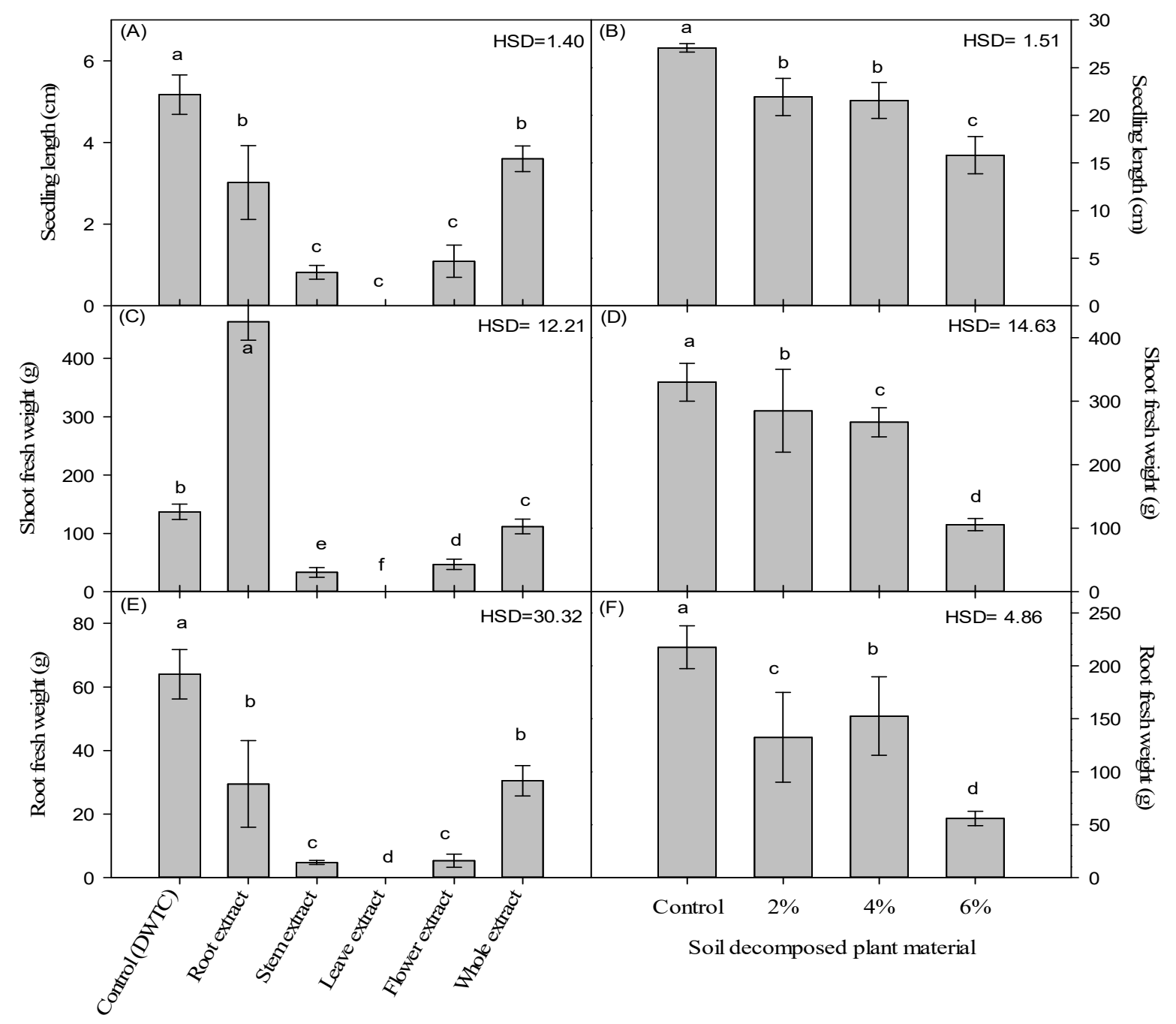

Figure-3: phytotoxic effect of various plant parts and soil decomposed plant material of $L$. chinensis on seedling growth of rice.

Various concentration of plant decomposed material of $L$. chinensis, $6 \%$ decomposed plant material reduced the shoot and root fresh weight (105.75 and $55.75 \mathrm{mg}$ ) of rice plant as compared to control treatment (330 and $217 \mathrm{mg}$ ). Shoot dry weight of plant express the total dry matter production during their growing season. Shoot dry weight of $O$. sativa plant as inclined by the aqueous extract of different plant part of $L$. chinensis and soil decomposed plant material were presented in figure-4 (A \& $B$ ). From aqueous extract bioassay leaf extract show maximum toxicity at par with stem extracts $(5.15 \mathrm{mg})$ whereas maximum dry biomass of shoot was chronicled in controlled condition (23.50 $\mathrm{mg}$ ) but similar with root and whole plant extract (17.35 and $16.37 \mathrm{mg}$ ).

In soil decomposed plant bioassay, highest reduction in shoot dry weight $(31.30 \mathrm{mg}$ ) were observed in pot having $6 \%$ decomposed plant material as compared to control condition ( $58.57 \mathrm{mg}$ ) at par with treatment having 2 and $4 \%$ soil decomposed plant material. Root dry 
biomass of rice as predisposed by the aqueous extract and soil decomposed plant material significantly reduced Figures 4 ( C \& D). From aqueous extract highest root dry weight was chronicled in control condition (17.47 $\mathrm{mg})$ whereas least were noted in treatment that received stem extract $(0.37 \mathrm{mg})$ statistically similar with root, leaf, flower and whole plant extract. In case of soil decomposed plant material root dry weight show non-significant result. Seedling weight is generally appearance of energetic growth of germinated/emerged seed showed in fig-4 ( $E, F)$. Aqueous extract of stem extract significantly reduced the seedling biomass $(5.52 \mathrm{mg}$ ) of rice as compared to control condition (40.97 mg). Seedling vigor index (SVI) is an overall performance of seed germination and seedling growth of germinated/ emerged seed Figures 4 ( $G$ \& $\mathrm{H})$.

Seedling vigor index (SVI) of rice was inclined by the aqueous extract of $L$. chinensis and lowest vigor index was recorded from stem extract (35.15) which was statistically similar with flower extract (59.07) while maximum SVI was recorded in control treatment (517.75). Whereas in soil decomposed plant material, highest SVI were recorded in soil without any plant material (2503) and minimum (957) were recorded in treatment having $6 \%$ decomposed material of $L$. chinensis. Whereas, comparable to our outcomes leaf extract of Trianthema portulacastrum maximally condensed the seedling length of rice (Mubeen et al., 2012). Similar to our results (Putnam, 1994; Bonanomi et al., 2007) notarized that increase in soil residues decrease the plant growth of various plants.

Our observations are in contrast with the findings of (Chi, 2011) who stated that decomposed residues of $E$. ulmoides enhanced the root growth and undecomposed materials significantly reduce the root growth of target plant. In our study, aqueous extract and soil decomposed litters substantially inhibit the seedling length and seedling biomass of rice emerged plant. Similarly (Patil, Hedge, 1988) demonstrated that different extracts of weed meaningfully retard the seedling growth of Triticum aestivum L. while seedling biomass of $T$. aestivum and other cereals were decreased when treated with aqueous extract of parthenium (Maharjan et al., 2007; Tefera, 2002).

According to (Beiber, Hoveland, 1968) incorporation of Coronilla veria L. plant residues into the soil were found to be phytotoxic to $C$. veria seedling growth. Similar with the investigation of (Chopra et al., 2017) stated that $E$. colona and $C$. iria had strong allelopathic potential significantly hampered the growth and development of rice and soybean. Similarly, (Xuan et al., 2005) stated that chemicals released allelopathic plant incorporated into the soil cause inhibition of germination and seedling growth of various species whereas soil decomposed plant material showed non-significant results. 


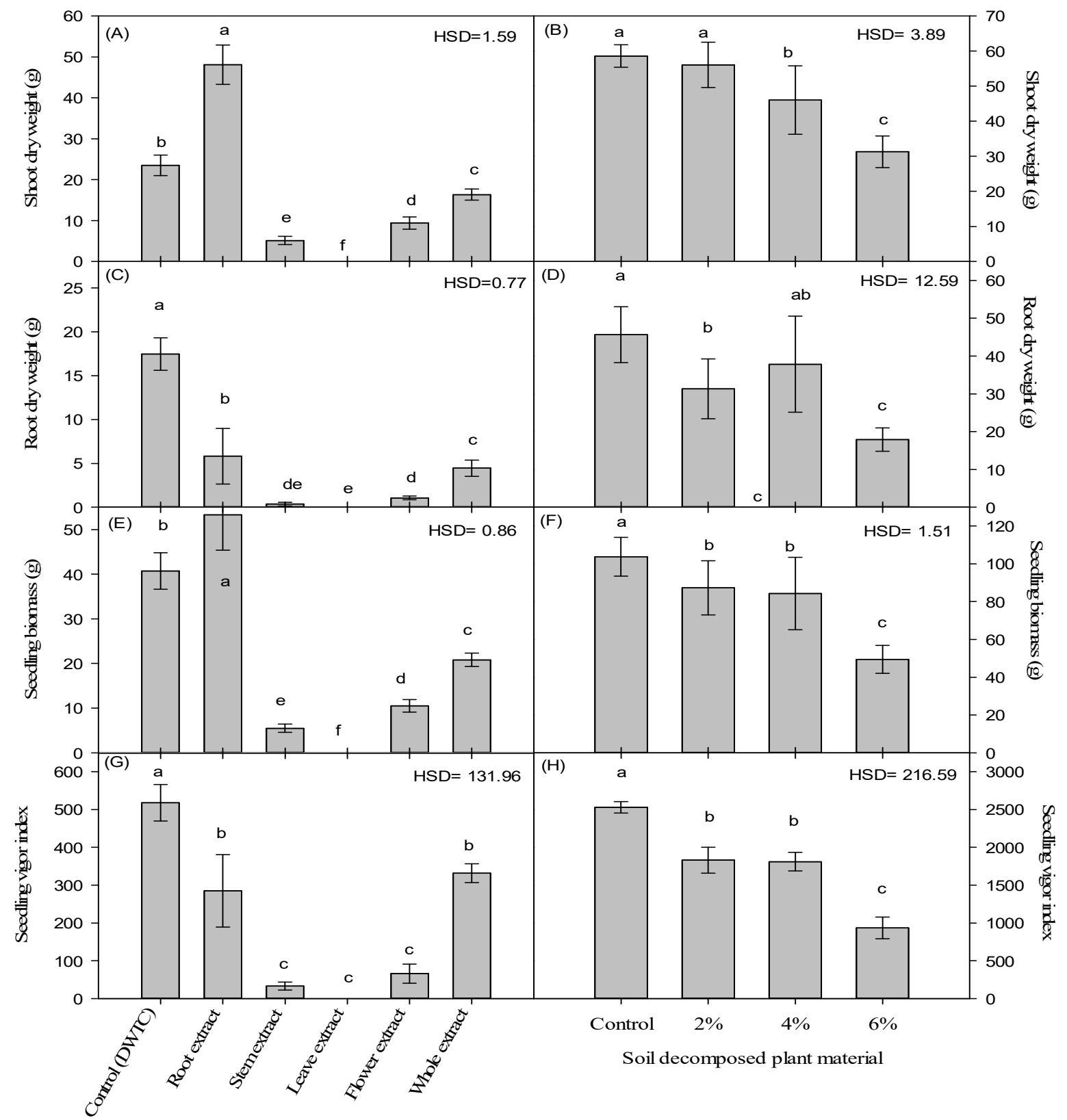

Figure-4: phytotoxic effect of various plant parts and soil decomposed plant material of $L$. chinensis on seedling growth of rice.

results have been reported by Safdar et al. (2014) that leaf watery concentrates of parthenium showed maximum phytotoxic effect against the SVI of Zea mays L. Growth and development of crop plants depends upon the cell division and in instance of allelochemicals that directly released from the plants or after decomposition of plant materials inhibited the cell division conveyed by (Hussain et al., 1984; Putnam, Chung, 1986; Rice, 1984). 


\section{Conclusion}

Present study discovered that aqueous extract of various plant parts and soil decomposed plant materials of $L$. chinensis significantly hampered the performance of rice. In first experiment, aqueous extract of leaves had strong allelopathic potential that fully inhibit the germination of rice seed, while stem extract reduced both the germination and growth of rice as associated to control condition. In second experiment, soil having $6 \%$ decomposed plant residue significantly inhibit the emergence and development performance of rice as compared to soil without any decomposed plant material. Furthermore, allelochemicals that released accountable for the decline of germination and growth of crop should be uprooted from field and need a comprehensive plane for management of red sprangletop.

\section{Acknowledgements}

This experiment is a part of thesis for a PhD degree of the author administered by the second and third at the department of Agronomy, College of Agriculture, University of Sargodha, Pakistan. Author of this examination enormously recognize the Agronomic research laboratory staff for shrouded kind collaboration. 


\section{REFERENCE CITED}

Anderson, W.P., 1983. Weed-crop competition. pp: 15-33. In Weed Science: Principles, 2nd ed., West Publishing Company, St. Paul, Minn., USA.

Aziz, A., A. Tanveer, A. Ali, M. Yasin, B.H. Babar and M.A. Nadeem, 2008. Allelopathic effect of cleavers (Galium aparine) on germination and early growth of wheat (Triticum aestivum). Allelopathy J., 22: 25-34.

Beiber, G.L. and C.S. Hoveland, 1968. Phytotoxicity of plant material on seed germination of crownvetch, Coronilla varia L. Agronomy. J. 60: 185-188.

Bonanomi, G., V. Antignani, C. Pane and F. Scala, 2007. Suppression of soilborne fungal diseases with organic amendments. J. Plant Pathol., 89: 311-340.

Burhan, N. and S.S. Shaukat, 1999. Allelopathic potential of Argemone mexicana L., a tropical weed. Pak. J. Biol. Sci., 2: 1268-1273.

Chi, M., 2011. Allelopathy of different agroforestry systems in the Weibei Area of Shaanxi. Master, Northwest A\&F University, Yangling, China

Khan, N., I.U. Khan, M.A. Khan and H. Khan. 2004. Major rabi and kharif weeds of agronomic crops of district Bannu. Pak. J. Weed Sci. Res. 10: 7986.

Chopra, N., G. Tewari, L.M. Tewari, B. Upreti and N. Pandey, 2017. Allelopathic Effect of Echinochloa colona L. and Cyperus iria L. Weed Extracts on the Seed Germination and Seedling Growth of Rice and Soyabean. Advances in Agriculture, https://doi.org/10.1155/2017/57485 $\underline{24}$
Coolbear, P., A. Francis and D. Grierson. 1984. The effect of low temperature pre sowing treatment under the germination performance and membrane integrity of artificially aged tomato seeds. J. Exp. Bot., 35: 16091617.

Das, N.R., and S. Choudhury, 1996. Allelopathic effects on rainfed jute under tillage and nitrogen by weed Vandellia scabra benth. The Wor. W., 4(1 and 2): 11-16

Economou, G., O. Tzakou, A. Gani, A. Yannitsaro and D. Bilalis, 2002. Allelopathic effect of Conyza albida. Ecology, 17: 2021-2034.

Einhellig F.A. 1987. Interactions among allelochemicals and other stress factors of the plant environment. pp. 343-357. In Symposium on Allelochemicals: Role in Agriculture and Forestry, G.R. Waller (ed.), ACS Symposium Series NO. 330, Am. Chem. Soc., Washington, D.C.

Ellis, R.A. and E.H. Roberts. 1981. The quantification of aging and survival in orthodox seeds. Seed Sci. and Tech., 9: 373-409.

Farooq, M., S.M.A. Basra, K. Hafeez and N. Ahmad. 2005. Thermal hardening: a new seed vigor enhancement tool in rice. Acta Botanica Sinica, 47: 187193.

Fischer, N. H. and L. Quijano, 1985. Allelopathic agents from common weeds: Amaranthus palmeri, Ambrosia artemisiifolia, and related weeds.

Florkowski, W. J., and G. Landry, 2002. An economic profile of golf courses in Georgia: course and landscape maintenance. Georgia Agricultural Experiment Stations, College of Agriculural and Environmental Sciences, the University of Georgia. 
Guenzi, W.D., and T.M. McCalla, 1966. Phenolic acids in oats, wheat, sorghum, and corn residues and their phytotoxicity. Agronomy J., 58: 303304

Hamayun, M., F. Hussain, S. Afzal and N. Ahmad, 2005. Allelopathic effects of Cyperus rotundus and Echinochloa crusgalli on seed germination, plumule and radical growth in maize (Zea mays L.). Pak. J. W. Sci. Res., 11: 81-84.

Hayyat, M.S., M.E. Safdar, M. Asif, A. Tanveer, L. Ali, R. Qamar, H.H. Ali, N. Farooq,H.M.A. Javeed and Z.H. Tarar. 2020. Allelopathic effect of wasteland weeds on germination and growth of winter crops. Planta Daninha.v.38: e020173626.

Hernandez-Aro, M., Hernandez-Perez, R., Guillen-Sanchez, D. and TorresGarcia, S. 2016. Allelopathic influence of residues from Sphagneticola trilobata on weeds and crops. Planta Daninha, 34(1): 81-90.

Hussain, F., M.I. Zaidi and S.R. Chughtai, 1984. Allelopathic effects of Pakistani Weeds: Eragrostis poaeoides P. Beauv. Pak. J. Sci. Ind. Res., 27: 159-164.

Karim, R. S., A.B. Man and I.B. Sahid, 2004. Weed problems and their management in rice fields of Malaysia: an overview. Weed Bio. and Manag., 4(4): 177-186.

Katoch, R. A. Singh and N. Thakur, 2012. Effect Of Weed Residues On The Physiology Of Common Cereal Crops. Int. J. Engi. Res. Appl., 2: 828-834.

Kumar, M., J.J. Lakiang and B. Gopichand. 2006. Phytotoxic effects of agroforestry tree crops on germination and radicle growth of some food crops of Mizoram. Lyonia 11(2): $83-89$
MacFarlane, T.D., 1987. Poaceae subfamily Pooideae. In: Grass Systematics and Evolution (eds TR Soderstrom, KW Hilu, CS Campbell \& ME Barkworth), pp. 265-276. Smithsonian Institute, Washington, USA.

Maharjan, S., B.B. Shrestha and K.J. Pramod, 2007. Allelopathic effects of aqueous extract of leaves of Parthenium hysterophorus L. on seed germination and seedling growth of some cultivated and wild herbaceous species. Sci. World, 5(5): 234- 243.

Molisch, H., 1937. Der Einfluss einer Pflanze auf die Andere-Allelopathic. Fischer, Jena, Germany, 31: 12-16.

Mubeen, K., M.A. Nadeem, A. Tanveer and Z.A. Zahir. 2011. Allelopathic Effect of Aqueous Extracts of Weeds on the Germination and Seedling Growth of Rice (Oryza sativa L.). Pak. J. Life Soc. Sci., 9(1): 7-12

Patil, T.M. and B.A. Hedge. 1988. Isolation and purification of sesquiterpene lactone from the leaves of Parthenium hysterophorus L. its allelopathic and cytotoxic effects. Current Sci., 42:1178-1181.

Putnam, A. and S. Chung. 1986. The Science of Allelopathy. Wiley Inter. Sci. Pub., pp. 174.

Putnam, A.R. 1994. Phytotoxicity of plant residues. In: Managing agricultural residues. (Ed.): P.W. Unger, Lewis Publishers, Boca Raton, FL, USA, pp. 285-314.

Rice, E.L., 1984. Allelopathy. 2nd Ed. Academic Press, New York. 421 pp.

Safdar, M.E., A. Tanveer, A. Khaliq, and M.S. Naeem, 2014. Allelopathic action of Parthenium and its rhizospheric soil on maize as influenced by growing conditions. Planta Daninha, 32: 243253. 
152 Muhammad Sikandar Hayat, Muhammad Ihsan Safdar et. al. Allelopathic potential of ...

Sawatdikarn, S., 2009. Allelopathy effects of red spragle (Leptochloa chinensis L.) Nees.) on some crops and weeds. In Proceedings of the 47th Kasetsart University Annual Conference, Kasetsart, 17-20 March, 2009. Subject: Plants, 335-342

Shaukat, S.S., P. Ghazala, D. Khan and M. Ahmed, 1985. Phytotoxic effects of Citrullus colocynthis L., Schard on certain crop plants. Pak. J. Bot., 17: 235-246

Shaukat, S.S., Z. Tajuddin, and I.A. Siddiqui. 2003. Allelopathic potential of Launaea procumbens (Roxb.) Rammaya and Rajgopal: A tropical weed. Pak. J. Biol. Sci., 6(3): 225230

Tanveer, A., M. Tahir, M.A. Nadeem, M. Younis, A. Aziz and M. Yaseen, 2008. Allelopathic effects of Xanthium strumarium L. on seed germination and seedling growth of crops. Allelopathy J., 21: 317-328.

Tefera, T., 2002. Allelopathic effects of Parthenium hysterophorus extracts on seed germination and seedling growth of Eragrostis tef. J. Agron. Crop Sci., 188(5): 306-310.

Turk, M.A., and A.M. Tawaha, 2003. Allelopathic effect of black mustard (Brassica nigra L.) on germination and growth of wild oat (Avena fatua L.). Crop Prot. 22: 673-677.

Weir, T.L., S.W. Park and J.M. Vivanco, 2004. Biochemical and physiological mechanisms mediated by allelochemicals. Current Opin. Plant Biol., 7: 472-479.

Weston, L. A., 2005. History and current trends in the use of allelopathy for weed

management. HortTechnology, 15(3): 529-534.

Xuan, T.D., S. Tawata, T.D. Khanh and I.M. Chung, 2005. Cropping and

Forage Systems/ Crop Ecology/
Organic Farming Faculty of
Agriculture, University of the
Ryukyus, Okinawa, Japan
Decomposition of Allelopathic Plants
in Soil. J. Agron. Crop Sci., 191:
162-171.

Zimdahl, R.L., 2007. Fundamentals of Weed Science. Third Edition. Academic Press, an imprint of Elsevier, pp. 228. 